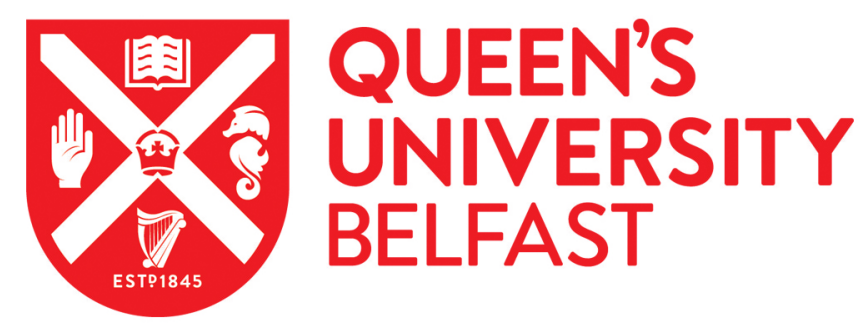

\title{
Memory, Truth and Justice: Understanding the experience of victims of terrorism and political violence. The cases of the United Kingdom and Spain.
}

Serrano, A., Lynch, O., Argomaniz, J., \& Lawther, C. (2017). Memory, Truth and Justice: Understanding the experience of victims of terrorism and political violence. The cases of the United Kingdom and Spain. In Victims and Perpetrators of Terrorism: Exploring identities, roles and narratives. Routledge.

https://www.routledge.com/Victims-and-Perpetrators-of-Terrorism-Exploring-Identities-Roles-and-

Narratives/Lynch-Argomaniz/p/book/9780367338770

Published in:

Victims and Perpetrators of Terrorism: Exploring identities, roles and narratives.

\section{Document Version:}

Peer reviewed version

\section{Queen's University Belfast - Research Portal:}

Link to publication record in Queen's University Belfast Research Portal

\footnotetext{
Publisher rights

Copyright 2017 Routledge. This work is made available online in accordance with the publisher's policies. Please refer to any applicable terms of use of the publisher.
}

\section{General rights}

Copyright for the publications made accessible via the Queen's University Belfast Research Portal is retained by the author(s) and / or other copyright owners and it is a condition of accessing these publications that users recognise and abide by the legal requirements associated with these rights.

\section{Take down policy}

The Research Portal is Queen's institutional repository that provides access to Queen's research output. Every effort has been made to ensure that content in the Research Portal does not infringe any person's rights, or applicable UK laws. If you discover content in the Research Portal that you believe breaches copyright or violates any law, please contact openaccess@qub.ac.uk. 


\title{
Memory, Truth and Justice: Understanding the experience of victims of terrorism and political violence. The cases of the United Kingdom and Spain.
}

Agata Serranò, Orla Lynch, Javier Argomaniz and Cheryl Lawther

\begin{abstract}
The issue of victimhood has suffered comparative neglect by scholars interested in the study of terrorism and political violence. Traditionally, it has been the actions of violent groups and the response to them by the state that have tended to attract academic attention. More recently for governments whose populations have suffered protracted campaigns of violence perpetrated by sub-state armed groups, the protection of those affected has become a policy priority. However in order to provide appropriate assistance to victims of terrorism and political violence, a detailed and nuanced understanding of the social, personal and political needs of these individuals and their families is necessary.
\end{abstract}

With a view to developing our understanding of the needs of victims of terrorism and political violence, this chapter will examine the social and political needs of these individuals and their families. In attempting to conceptualise these needs, the importance of context cannot be underestimated therefore this paper focuses specifically on the case of the United Kingdom, including Northern Ireland (NI) as well as Spain, more specifically, the Basque Country. Using the analysis of semi-structured interviews conducted with both victims and representatives from victims' groups in both countries, 
In: Victims and Perpetrators of Terrorism: Exploring identities, roles and narratives. (London: Routledge, 2017: 18-37). Eds: Orla Lynch and Javier Argomaniz.

this contribution will specifically explore the key themes emergent from the data of memory, truth and justice.

\section{Introduction}

The issue of victimhood has suffered comparative neglect by scholars interested in the study of terrorism and political violence. Traditionally, it has been the actions of violent groups and the response to them by the state that have tended to attract academic attention (Schmid, 2012). More recently for governments whose populations have suffered protracted campaigns of violence perpetrated by sub-state armed groups, the protection of those affected has become a policy priority. However in order to provide appropriate assistance to victims of terrorism and political violence, a detailed and nuanced understanding of the social, personal and political needs of these individuals and their families is necessary.

With a view to developing our understanding of the needs of victims of terrorism and political violence, this chapter will examine the social and political needs of these individuals and their families. In attempting to conceptualise these needs, the importance of context cannot be underestimated therefore this paper focuses specifically on the case of the United Kingdom, including Northern Ireland (NI) as well as Spain, more specifically, the Basque Country. Using the analysis of semi-structured interviews 
In: Victims and Perpetrators of Terrorism: Exploring identities, roles and narratives. (London: Routledge, 2017: 18-37). Eds: Orla Lynch and Javier Argomaniz.

conducted with both victims ${ }^{1}$ and representatives from victims' groups in both countries, this contribution will specifically explore the key themes emergent from the data of memory, truth and justice.

The themes of memory, truth and justice are central issues in the literature concerning victims' needs (Lawther, 2014) and are often understood as having a triple dimensionality: they are needs related to the experience of terrorism and political violence, individual and collective rights that must be bestowed due to the responsibility the state owes to the victims, but at the same time their recognition and delivery are constructed as a collective responsibility of society as a whole (Alonso and Serranò, 2015). Although these three dimensions are inextricably linked, they must be analysed individually in order to construct a grounded understanding of their characteristics and the features of their interactivity.

It must be pointed out that memory, truth and justice are also located simultaneously in the public and private spheres of victims' experiences. For instance, memory, on the one hand, can be instrumental for victims to attain some measure of personal resolution, often termed 'closure'; on the other, memory is constructed as a public moral duty, an obligation on society to remember the crimes committed. Moreover, memory can also be considered a tool for preventing future atrocities through the recognition of the tragedy of loss suffered by the victims and their families.

Truth is considered to be an individual need but can be also be seen as a collective societal right. It is therefore a very complex intangible notion related to historical narratives, 
In: Victims and Perpetrators of Terrorism: Exploring identities, roles and narratives. (London: Routledge, 2017: 18-37). Eds: Orla Lynch and Javier Argomaniz.

issues of legacy, politicisation and power. Closely related to issues of truth are the social interpretations of justice and delivering justice. The delivery of justice for the victims and access to the truth can run opposite to some interpretations of the greater good, as we saw in the commentary following the arrest in 2014 of Gerry Adams. ${ }^{2}$ Dominant peace narratives, expectations of moving on, the passage of time and lingering sectarian divides impact on the realities of truth and justice. While depending on the dominant narrative, truth can be portrayed as an achievable end, a subjective inaccessible aspiration, or a commodity in post-conflict societies.

This study will examine the individual interpretation of these notions by both victims and representatives from victims' groups in the UK and Spain. Most participants were victims of ethno-nationalist organisations such as Euskadi Ta Askatasuna (ETA), the Provisional Irish Republican Army (PIRA), the Ulster Volunteer Force (UVF) or the Ulster Defence Association (UDA). A minority of the Spanish sample were targeted by extreme-rightwing groups active in the country during the process of transition to democracy in the late 1970s/early 1980s (Rodríguez Jiménez, 1997). The findings are based on the analysis of 46 semi-structured qualitative interviews (23 in the UK and 23 in Spain). The UK data was collected between 2011 and 2013 as part of an EU-funded study that comparatively analysed the needs of victims of terrorism in Spain and the UK, where Lynch and Argomaniz were the principal investigators (Lynch and Argomaniz, 2013). ${ }^{3}$ The Spanish data comes from field work conducted by Agata Serranò during the years 2010-2012 (Serranò, 2012) ${ }^{4}$. Participants were recruited through the established networks of the authors but also through opportunistic and snowball sampling. Interviews ranged in length from one hour to four hours. The interviews were conducted on the premises of 
In: Victims and Perpetrators of Terrorism: Exploring identities, roles and narratives. (London: Routledge, 2017: 18-37). Eds: Orla Lynch and Javier Argomaniz.

victims' organisations, in private homes and in public locations (coffee shops, hotels). The interviews were recorded where permission was secured and consent was achieved in writing from all participants. Ethical permission was granted for this work from the University of St Andrews, Scotland.

\section{Memory}

In this section memory - understood as both the personal and collective recollections of individuals killed by terrorism and political violence, including their place in historic constructions of the violence - is closely linked with two other issues that appear frequently amongst both the UK and Spanish victim populations: remembrance and memorialisation. Remembrance can be defined as the act of remembering victims of terrorism and political violence and relatedly memorialisation is the way they are honoured and commemorated in the public sphere.

These three notions emerged as higher order themes in the analysis of the interview data from both the UK and Spanish populations. There are however important distinctions to be made in the nature and place of these narratives in each locale. As we will see, in the testimonies of victims of terrorism in Spain, memory encompasses three core implications. Firstly, memory is a collective responsibility that should serve to delegitimise the narrative of those perpetrating violence. Secondly, it is constructed as the public recollection of the political significance of victims of terrorism and, thirdly, it is thought to serve as a means of preventing future forms of violence. Amongst the victim population in Spain the concept of an objective truth dominates victims accounts of their needs. The desire to debunk any myths propagated by groups like ETA is intrinsically 
In: Victims and Perpetrators of Terrorism: Exploring identities, roles and narratives. (London: Routledge, 2017: 18-37). Eds: Orla Lynch and Javier Argomaniz.

linked to the preservation of the memory of their lost love ones. In effect, an objective truth would serve to protect the memory of their loved ones through the outright social and political rejection of the motives of the terrorist organisation:

"The truth is the only thing we still have ...we are perfectly aware of why they killed our family members and it was to impose their political project...we, as victims of terrorism, have a clear political significance and as such we still have a lot to do to delegitimise terror [caused by ETA and its political environment]. Delegitimising means destroying the huge farce that was drummed into us for so many years of our recent history and according to which there is a two-sided conflict with deaths on each side in the Basque Country. This is the distortion of history by the nationalists [radical and moderate]... against the truth and it needs to be faced to defend the memory of my brother

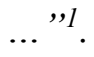

In Northern Ireland however, the idea that there could be an objective truth that might capture the experience of all parties to the conflict was generally rejected. Given existing societal divides, the history of sectarianism, the many parties to the conflict and the existence of a peace process there is little expectation of an objective truth emerging in that context. There are of course exceptions to this and some communities (or more accurately sub sections of communities) in the North of Ireland support the belief that there should be an objective truth that would serve as a direct challenge to the narratives of the paramilitary groups and their political wings. Narratives of self-defence,

\footnotetext{
${ }^{1}$ Interviewee - Victim (Spain).
} 
In: Victims and Perpetrators of Terrorism: Exploring identities, roles and narratives. (London: Routledge, 2017: 18-37). Eds: Orla Lynch and Javier Argomaniz.

oppression, victimisation and the violation of human rights are particularly controversial in this context.

Amongst the participants in this study, it emerged that for the Northern Irish sample, memory, memorialisation, remembrance and forgetting were constructed as personal and local processes inherently related to the divisions in their society. For example, who could and should be remembered were significant issues for many of the participants. Memorialisation and remembrance were controversial as the nature of victimhood was not fixed, especially in cases where betrayal of one's identity group was suggested (e.g. the death of an informer). This issue was particularly problematic in the case of perpetrator-victims: individuals who were injured or killed due to their own involvement in conflict violence:

"I think the couple of times it has arose [sic] within communities it has been quite controversial because how do people on the Falls reconcile with having some informer's name on a memorial or how do people in the Shankill commemorate by having a Provo's name on the same mural that is dedicated to their loved one?"5

The solution to this complexity has been a localisation of remembrance in many instances.

"I think people have their own events which are significant and I think it is about community support for those." 6 
In: Victims and Perpetrators of Terrorism: Exploring identities, roles and narratives. (London: Routledge, 2017: 18-37). Eds: Orla Lynch and Javier Argomaniz.

While this localisation of memorialisation is dominant, for some of the larger and more visible attacks (e.g. the Omagh Bombing), there is a deliberate effort to have an allinclusive, multi-denominational and international participation in memorialisation.

While there is a very strong local community-based process underway in NI whereby victims, their families and all those who experienced the Troubles have access to grassroots organisations who prioritise the issues of memory and remembrance; there is a distinctly different attitude to remembrance for participants in NI as opposed to those in Spain. In this NI sample, about half of the participants addressed the issue of memory and remembrance despite not being directly asked about them. The point of divergence from the Spanish sample was the issue of subjectivity: As will be discussed in the next section, the Spanish groups and victims unconditionally attest to the need for memory, remembrance and memorialisation in the public sphere. In NI there was a more nuanced understanding of history, perspective and possibility. For them, there was little hope of broader public memorialisation and a distinct recognition that everyone had their own truth.

"How do we accept that this is our joint history, however painful and we need to build for the future?"7

"We need to be honest with people on expectations on that [public memorialisation]"8 
In: Victims and Perpetrators of Terrorism: Exploring identities, roles and narratives. (London: Routledge, 2017: 18-37). Eds: Orla Lynch and Javier Argomaniz.

For the victims in NI, memorialisation, while a very public debate, is an intensely private (local) experience. Efforts to remember are predominantly efforts to document the lives and the experiences of those who were killed. However, there is some politicisation of the initiatives to remember and memorialise in an effort to control the truth as it might emerge.

"There is a need sometimes to correct the corporate memory of the RUC".

The dominant narrative of victims of terrorism in Spain encompasses the following issues: the innocence of victims; the notion of the public sacrifice of victims; and the inviolability of the Rule of Law in opposition to the violent terrorist acts. This position implicitly means that there is an accepted truth represented by the need to publicly respect, remember and appreciate the loss and suffering of victims of terrorism (Etxeberria, 2009).

For many interviewees, remembering those injured and killed means remembering their innocence and their sacrifice and these notions are an essential part of the identity of victims:

[Victims of terrorism] deserve, I think, the respect of every citizen because in the end their family members were murdered precisely because they defended [...] the highest values of our Legal System that are set out in Article 1 [of the Spanish Constitution $]^{10}$. I certainly think that they $[$ victims of terrorism] deserve respect [...]. I respect them simply because of the 
In: Victims and Perpetrators of Terrorism: Exploring identities, roles and narratives. (London: Routledge, 2017: 18-37). Eds: Orla Lynch and Javier Argomaniz.

enormous sacrifice in defence of those values that their families have had to make."11

Innocence and sacrifice are qualities integral to the accounts of interviewees as they recall the victims; these qualities are held in opposition to those who chose violence and these notions are used as a tool to de-legitimate terrorism by highlighting the disparity between the innocence of the victim and the guilt of the perpetrator. For this group there is no grey area in the definition of victims of terrorism, if a person has taken up arms against another, they are clearly excluded from this category.

For victims' organisations in Spain, memory is not a local issue, but should be a national collective responsibility. And not only should the individuals who were killed, injured, threatened and forced to abandon their homeland and their families be remembered, but their remembrance should be a useful means to challenge and refute the ideology and motive of those who use violence. Memory is in fact considered to be a moral duty and a collective responsibility that should concern everyone who respects democracy and constitutional values (Serranò, 2012, 257). Furthermore, many participants consider the testimonies of survivors and relatives of victims to be a historical legacy; they believe that disseminating the stories will serve to enrich society as a whole and is essential for future generations to understand their past (Serranò, 2015, 22). In effect, the voices of victims are considered to be useful tools in peacebuilding and the prevention of violence (Serranò, 2015, 91-108). They shine light on the reality of violence, a reality that is often hidden or concealed, silenced and deprived of its meaning (Mate, 2008): 
In: Victims and Perpetrators of Terrorism: Exploring identities, roles and narratives. (London: Routledge, 2017: 18-37). Eds: Orla Lynch and Javier Argomaniz.

"Keeping memory alive is, I think, an obligation for future generations to know the story and learn from history. If we remove that memory for future generations they will not even have the possibility of searching for a way to go forward." 12

From the data analysed in this research it is evident that the Spanish participants consider themselves and their experiences to have a public dimension and a political significance that deserve to be recognised by society as a whole. For these people, being a victim of terrorism is not merely being a victim of violence; it means being the victim of a crime whose intention was to destroy the res publica. Terrorism is thus understood as being an attack on the Rule of Law, on human rights and on the Spanish state (Arregi, 2008). Victims therefore expect their experience to be recognised as an event that transcends the private trauma experienced:

"In short, our relatives were killed because they defended a political position, political values, principles, and were killed just because of that. And I truly believe that if the principles and values that my father was killed for were made abstract it would be a betrayal of his memory. I believe that remembering victims of terrorism is essential and it must also somewhat transcend the private memories of families. In addition to this private memory I think we victims need a public memory or the preservation of a public memory of our family, because their murder was, in essence, public. And of course, public memory for me and the preservation of the public 
In: Victims and Perpetrators of Terrorism: Exploring identities, roles and narratives. (London: Routledge, 2017: 18-37). Eds: Orla Lynch and Javier Argomaniz.

memory of my father is essential, essential for me not to have the feeling that his sacrifice [was in vain]."13

In conclusion, in Spain the narrative of victims of terrorism focuses on the public recognition and remembrance they deserve since it is implied in their plight that through their sacrifice they acted to defend the constitutional values of non-violence and the support for the rule of law.

\section{Visibility, recognition and memorialisation}

For many victims in the UK and Spain, memory, remembrance and memorialisation are closely linked to two other categories that appear frequently in their discourse: visibility and recognition. In effect, memorialisation entails victims being visible and publicly recognised. The notion of 'public' is understood differently in each context. In the case of Spain, to be publicly recognised refers to a national and international agenda whereas in NI there is oftentimes an effort to bypass the national arena and focus on either the local and/or the international arenas.

On the one hand, it can be assumed that offering victims the possibility of sharing their own experiences with others (public memory) provides them with an effective way of dealing with their own personal trauma (Sutil and Lázaro, 2007). Different sectors of civil society may expect from victims to "wipe the slate clean" following public recognition, to move on: 
In: Victims and Perpetrators of Terrorism: Exploring identities, roles and narratives. (London: Routledge, 2017: 18-37). Eds: Orla Lynch and Javier Argomaniz.

"It can be a very offensive word [memorialisation] to many victims because the term implies that you have gone through this process and you should move to a different process where you put that behind you and as it were, almost forget it."'14

Similarly there have been instances where victims in NI have been portrayed as spoilers of the peace process due to the perception of their unwillingness to move on from the issues of memory and remembrance (Hamber and Wilson, 2003). Given this, international and local initiatives are much less problematic as the focus is not on the division in society in NI, but on the issues of loss, destruction, violence and terrorism.

However, it is important to note that in NI memorialisation and remembrance continue to be controversial. In fact, the memorialisation of the Northern Ireland conflict has found expression in a plethora of commemorative acts conducted by a long list of state and nonstate agencies. These include the security forces, Loyalist and Republican paramilitary organisations, political parties, victims' groups and even private individuals. Walking around Belfast one can witness this very local phenomenon on every street corner. Consequently, memorialisation is partisan, local and fragmented and a shared and collective remembrance remains politically contentious and very difficult in practice.

On the other hand, many victims of terrorism in Spain believe that, since they have sacrificed their life, their limbs, their health, and their loved ones for Spanish society, they deserve to be publicly recognised for their suffering. In addition to a long list of national, regional and local initiatives that have taken place in the past to recognise the victims, the 
In: Victims and Perpetrators of Terrorism: Exploring identities, roles and narratives. (London: Routledge, 2017: 18-37). Eds: Orla Lynch and Javier Argomaniz.

most important of these efforts, a victims' memorial centre (Centro Memorial de las Victimas) is expected to open its doors in Basque Country in 2017. ${ }^{15}$ However, although many interviewees view with satisfaction the public recognition received, especially from the nineties onwards, there are those who believe that memorialisation has become institutionalised and sometimes distorts the meaning of such acts:

"For me there are now many tributes that are not very sincere. We have not felt that care from government until recently. We've been suffering a lot...things have changed of course and are quite...I really think that now the absolute opposite will happen... I think we've gone from not having any tributes to...I myself have now had many tributes. [...] To be honest, what is truly happening now is that I've had enough of all these tributes..."16.

While this type of national recognition exists in NI, it does so only for those who died whilst actively serving in the police, military and security services, in effect giving voice to only one group of victims:

“..there's a hierarchy, some are more important than others." 17

Visibility is an overarching concern among UK interviewees. Victims have a widely held perception that they lack a voice both as individuals and as a group and that their own personal stories have remained invisible and untold outside their own community. They see that there is fatigue regarding victims of terrorism, in particular for victims of the Troubles, and especially for victims who are outside of Northern Ireland: 
In: Victims and Perpetrators of Terrorism: Exploring identities, roles and narratives. (London: Routledge, 2017: 18-37). Eds: Orla Lynch and Javier Argomaniz.

"Oh my god, are you still going on about that? It was 20 years ago"18

"As far as they are concerned [the public] the Troubles are over"19

This invisibility is a traumatising experience for victims (Arteta, 2007:85; Echeburúa and Guerrica, 2006). Denying visibility and recognition to victims is one of the goals that violent groups usually seek (Sabucedo, Blanco and de la Corte, 2003). To avoid this happening, victims in Northern Ireland are concerned with creating documentary proof of individual truths, to produce their own testimony so that their stories as victims are documented and made visible to the rest of society. And while it is often important to victims and their families to tell their story publicly, remembering through documenting their story can be useful to facilitate the psychological wellbeing of those who suffered:

"There should be more records, there should be more done for remembering" 20

\section{Truth}

In the accounts given by victims of ETA in Spain, exposing the truth about the past is considered a fundamental tool in the de-legitimisation of the terrorists' rhetoric and a mechanism to challenge the group's extremist discourse. On the other hand, an absence 
In: Victims and Perpetrators of Terrorism: Exploring identities, roles and narratives. (London: Routledge, 2017: 18-37). Eds: Orla Lynch and Javier Argomaniz.

of truth is regarded as a source of re-victimisation on an individual level that prevents victims from achieving closure.

In contrast, in the United Kingdom - and especially in NI - perceptions of truth within the victims' community are disputed. Truth is a post-conflict by-product of the violence inflicted in a divided society by violent groups in two opposed communities. Although the truth is an important element for their own experiences of victimhood, most participants are sceptical of society's capacity to reach a collectively agreed upon and a 'shared truth' about the conflict.

\section{Truth as de-legitimisation of the terrorist narrative}

As argued by Sabucedo, Blanco and de la Corte (2003), terrorist groups create a historical narrative in which the responsibility of the violent 'conflict' is attributed to an external enemy. Such 'external attribution of responsibility' seeks to foster popular support for the political objectives of the terrorist group and to serve as justification for the attacks it has committed. To reinforce that justification, political violence is presented by the organisation as an inevitable response, a necessary reaction to a conflict instigated by the adversary or as an act of legitimate defence (Serranò, 2009, 78). In accordance with this logic, ETA's narrative places the responsibility for the conflict on the Spanish State, describing it as an 'armed confrontation' 
In: Victims and Perpetrators of Terrorism: Exploring identities, roles and narratives. (London: Routledge, 2017: 18-37). Eds: Orla Lynch and Javier Argomaniz.

${ }^{21}$ with two adversaries: the 'repressive Spanish State' and the 'repressed Basque people' (Aulestia, 1993; Mata, 1993).

ETA's victims strongly oppose this discourse which is also supported by the 'abertzale left' -the milieu of groups, structures, political and social players that have traditionally supported ETA's violence; in effect, the victims portray ETA as a criminal organisation. In our study, interviewees stress how in the Basque Country there has never been a 'twosided conflict' but a long terrorist campaign that targeted Spanish democracy and its citizens:

"In the Basque Country there are not two warring communities, there is no conflict here, we do not need a mediator, here the only thing that is required is that ETA lay down its arms and be involved in politics like everyone else. This is not [Northern] Ireland, this is not South Africa. Here there are not two communities. Here we are Basques, no more, that's it. Basques, yes. There are Basques that go back many generations, others arrived later but here you do not distinguish whether one is Basque of seven generations or got here the day before yesterday. The conflict is fictitious, it is a lie." 22

Challenging the notion of a 'two-sided conflict' is essential for many of ETA's victims as is clearly differentiating innocent people (victims of terrorism) from perpetrators (terrorists). To respond to the version of history constructed by ETA and its supporters, 
In: Victims and Perpetrators of Terrorism: Exploring identities, roles and narratives. (London: Routledge, 2017: 18-37). Eds: Orla Lynch and Javier Argomaniz.

many victims believe that a clear or objective truth must be told, a story that has two protagonists: murderers and victims:

"Victims are those who were murdered for no reason-because ETA kills

for no reason... and anyway, there is no reason for killing. Of course, they...

- to call them something - they [are] murderers. " 23

For victims and representatives of victims, the rejection of ETA's and the Abertzale Left's version of history is based on the conviction that victim and perpetrator can never be put on the same level since the perpetrator, by carrying out a criminal act, makes use of their own will. . For ETA's victims it is therefore unacceptable to equate those who have suffered for being the unjustified target of a criminal act with those serving a sentence for having carried it out intentionally, or with those who were injured when a bomb they were assembling exploded (Alonso M., 2009: 11).

Given the construction of the identity of victims in Spain and given the narrative that addresses this identity, without the de-legitimisation of the terrorist narrative -be it that of ETA, the extreme right-wing, or jihadist, along with their sympathisers- victims believe truth will never be achieved in Spain. The truth and the history of victims depend heavily on the de-legitimisation of the terrorist narrative, on the rejection of the manipulation of the history of violence (Alonso R., 2012):

"Truth is telling the real story, what happened, not falsifying it, it means not 
In: Victims and Perpetrators of Terrorism: Exploring identities, roles and narratives. (London: Routledge, 2017: 18-37). Eds: Orla Lynch and Javier Argomaniz.

lying, it means not using instruments to spread the lie, do you understand? Truth can never be on their [the terrorists' and their followers] side, never, [because] they have lied and they lie and they lie again and the story repeats itself. We must not legitimate their huge farce that has been so insistently sold [to us] throughout our recent history that this is a two-sided conflict with fatalities on both sides." 24

"I believe that the victims are innocent, all of those who were murdered are innocent and future generations must know the truth about what happened so that these mistakes will not be repeated and it is very important that the country's history include this. ${ }^{25}$

Therefore, the representatives from victims groups who participated in this study demanded the right to truth which they consider to be not only an individual right but also a right of society as a whole. Consequently, truth is considered to be a fundamental and collective right that protects against the manipulation of the past.

\section{An attainable objective truth?}

In the UK perceptions of truth in the context of victimhood are fundamentally different from those that exist in Spain. It is acknowledged that the notion of truth, especially in NI is partial and limited (e.g. Smyth, 2003) and that each group (Republican and Loyalist) conceals their involvement in the conflict and with it the truth (Lawther, 2012). 
In: Victims and Perpetrators of Terrorism: Exploring identities, roles and narratives. (London: Routledge, 2017: 18-37). Eds: Orla Lynch and Javier Argomaniz.

Amongst the participants in NI, the concept of truth is entangled with that of blame. There is a general - and strategic - use of the idea of 'partial truth' to attribute blame onto the other community and to deny personal/in-group responsibility:

"They won't tell the whole truth." 26

'They' are Republicans, Loyalists, the 'Other', depending on who is speaking and the 'Other' is often assigned full responsibility for the conflict. Some representatives of victims acknowledge the impossibility of finding a consensual truth but they blame this on the political use of the victims' discourse by the representatives of the other community:

"For some people it's a system they want in place that will hammer the security forces and ignore what the Republicans did. "27

"Someone from the IRA for example they can say this and this happened but, are they going to tell the truth? Why would they?"28

With the intention of building a 'shared truth' about the Troubles considerable effort has been made to develop truth recovery processes in this region (e.g. Bell, 2003). However, there has been no formal government-led truth process and just a variety of initiatives in 
In: Victims and Perpetrators of Terrorism: Exploring identities, roles and narratives. (London: Routledge, 2017: 18-37). Eds: Orla Lynch and Javier Argomaniz.

the form of public enquiries related to single events during the Troubles have been undertaken (Cory, 2003; Cory, 2004a; Saville, Hoyt and Toohey, 2010; Morland, Strachan and Burden, 2011; MacLean, 2010; Requa, 2007).

Faced with the question of how important the truth is for victims of the Troubles, the majority of our respondents considered it to be a basic need. Truth was described in their accounts as a need for information in order to piece together an accurate representation of past injustices they and their families suffered:

“Who killed my sons, my brother, my wife?"29

For many interviewees, the truth about what happened could lead to the healing of the open wounds of the past, end the mourning and attain closure. Faced with the question of whether it would be better to attain the truth via a process of truth recovery, many respondents did not find that a truth recovery process in Northern Ireland could work at this moment in time. Some representatives of victim-led groups expressed their disagreement by using/showing violent imagery to illustrate its futility:

"Does anyone expect the person who cut people up, butchered them, put bombs in bars to sit and tell the truth? $?^{30}$ 
In: Victims and Perpetrators of Terrorism: Exploring identities, roles and narratives. (London: Routledge, 2017: 18-37). Eds: Orla Lynch and Javier Argomaniz.

Despite having highlighted the importance of truth for their own experiences of victimhood, participants were very sceptical that truth could be agreed upon publicly, that Northern Ireland's society could reach a collective truth.

\section{Justice}

The definition of justice in the context of victimisation is inherently complex and the term carries many connotations both within and between contexts (i.e. Breen-Smyth, 2007; Doak and O’Mahoney, 2011; Mate, 2008; González Zorrilla and Díaz Bada, 2012). The analysis of the interview data highlights important differences between both contexts mainly regarding whether participants consider that there is room for alternatives to the traditional retributive justice approach such as, for example, that of restorative justice. On the one hand, in the Spanish sample, the dominant narrative from organisations of Spanish victims is shaped by concerns regarding retributive justice. On the other hand, in the United Kingdom, and especially in Northern Ireland, the narrative from victims' organisations refers to both models of retributive and restorative justice.

\section{Justice as absence of impunity}

The concept of justice that emerges in the interviews carried out with the Spanish participants is very close to the notion of 'retributive justice': a theory of justice that considers penal punishment, if proportionate and assigned in the frame of the Rule of 
In: Victims and Perpetrators of Terrorism: Exploring identities, roles and narratives. (London: Routledge, 2017: 18-37). Eds: Orla Lynch and Javier Argomaniz.

Law, to be the best response to crime. In the accounts of interviewees, justice is an unequivocal need and a non-negotiable public right that a democratic state guarantees not only to victims of terrorism but all to members of society. In order to make this right effective for victims, perpetrators have to be investigated, tried and punished according to the principles of the Rule of Law. However, justice not only takes on the meaning of 'absence of impunity' in the narrative of many victims of terrorism in Spain but also that of reparation for the unjust harm caused:

"[we need] reparative justice in the broadest sense of the word. In short, to protect victims, to take care of them, to listen to them, to inform them and of course to avoid impunity. "31

As reparation and assistance to victims of terrorism, especially since the nineteen nineties, have been a priority objective of the public policy of the Spanish Government, comprehensive legislation has been introduced to address this issue. ${ }^{32}$ Nevertheless, in most cases, the Spanish State has been able to ensure reparation, although it came very late:

“Compensation also came late...they didn't pay us until 2000, from 1986 [the year of the attack] to 2000, that's a lot of years!" 33

However, justice understood as the investigation, trial and prosecution of culprits is complex and arguably difficult to achieve. Hundreds of incidences of murder 
In: Victims and Perpetrators of Terrorism: Exploring identities, roles and narratives. (London: Routledge, 2017: 18-37). Eds: Orla Lynch and Javier Argomaniz.

are still unsolved, some of which have exceeded the statute of limitations: ${ }^{34}$

“We can imagine who my father's murderer is, but there has not been a sentence, there is nothing. At that time he would have been a 19 or 20-yearold guy when he killed my father and they didn't manage to arrest him. It is outrageous because my case has exceeded the statute of limitations and nothing can be done now." 35

For many victims, whose cases are still unsolved, there is a sense of betrayal based on the realisation that the Spanish authorities have not delivered justice. In addition, the participant points out that allowing those responsible for terrorist activity to go unpunished has particular consequences for the victims (Lynch, Argomaniz, Serranò, 2015):

"Without justice there is nothing, you stop believing in everything, you have to think that those killed, our children, our parents, our siblings died because they were defending justice, were defending something that is supposed to be correct. So if there is no justice for the people who were killed for those beliefs you stop believing in everything. "36

"we just want a little justice, so that the damage can be repaired and we do not have to live the rest of our lives with a sick feeling in our stomach." 37 
In: Victims and Perpetrators of Terrorism: Exploring identities, roles and narratives. (London: Routledge, 2017: 18-37). Eds: Orla Lynch and Javier Argomaniz.

Other interviewees claim that some sectors of society have expectations around the potential for victims to forgive the perpetrators and in effect seek to encourage them to end their demands for justice in order to build a society based on reconciliation (Alonso R., 2009). However, for most of the victims interviewed justice is a need that can never be replaced by forgiveness because the former belongs in the public domain while the latter is a private matter (Serranò, 2014).

\section{Retributive justice and restorative justice}

A central difference between approaches of retributive and restorative justice is whether victims are seen as central or peripheral to the process of resolving past injustices. While for retributive justice the victim is generally peripheral to the formal criminal process which focuses on establishing sanctions for the crime committed, restorative justice places the victim in a central position of this process, which is linked to fundamental truths of reconciliation and healing (Ellwanger, 2004).

However other issues are of relevance in our efforts to understand the place of restorative and retributive justice post-conflict. In NI, due to the scale of the conflict, the difficulties policing the Troubles, the lack of usable evidence and the difficulty in defining 'victims', the likelihood of securing criminal convictions is negligible (Northern Ireland Affairs Committee, 2008). Additionally, the criminal justice system, as a tool of the State, is 
In: Victims and Perpetrators of Terrorism: Exploring identities, roles and narratives. (London: Routledge, 2017: 18-37). Eds: Orla Lynch and Javier Argomaniz.

contested, the police are viewed by some communities as inept and incapable and thus, the ability of police to work within these communities is limited (McEvoy \& Mika, 2001). Therefore, it has long been recognised that an alternative conception of justice was needed in NI, one that was not intertwined with the conflict, nor reliant on the success of criminal convictions (O’Mahoney, 2012).

As a solution for both the Loyalist and Republican communities, a community-based system of justice was considered as an option. As a result, in recent years, restorative principles began to emerge both within and outside of the criminal justice system in Northern Ireland (McCold, 2004). Restorative justice practices in Northern Ireland include victim-perpetrator mediation, education projects and cross-community initiatives (Gormally, 2006). Some community-based restorative justice schemes seek to mediate in neighbourhood disputes, implicitly limiting the role of legal professionals (McGrattan, 2010). However, more serious violent crime remains the responsibility of the formal justice system. Restorative justice principles have been championed in an effort to foster intra- and inter-community dialogue and conflict transformation (i.e., Eriksson, 2008).

In this project, amongst the Northern Irish participants, a distinction between restorative and retributive justice is made consistently throughout the interviews. In some accounts, the victims' need for justice is associated with notions of retributive justice: 'they want prosecutions', 'she is hoping that someone will be charged'. In general, representatives of victims evoked notions of retributive justice in their accounts of victims' personal narratives and often report the 'voices' of family members: 
In: Victims and Perpetrators of Terrorism: Exploring identities, roles and narratives. (London: Routledge, 2017: 18-37). Eds: Orla Lynch and Javier Argomaniz.

"She just wants to see justice for her son's death, that's all."

"I was talking to a mother whose son was murdered and she said to me 'I want who did this to my son to be put away, it's not fair that I suffer and this person is free. ", 39

In other accounts, non-victim-related representatives discuss the broader notion of restorative justice: 'it's not necessarily about putting people behind bars'. In these cases, the respondent generally reported the viewpoint of victims as a collective (i.e. 'families'), rather than evoking personal narratives:

"And there are really mixed feelings amongst the families in that there are one or two families who don't want anything for there to happen, there are one or two families who want absolute prosecution and there are a good deal of families in the middle who are so-so." 40

In this discourse, justice is seen as a mechanism for restoring the moral framework of society after the conflict. These particular perceptions of justice are generally linked to generational issues: it is argued that we need this to repair the moral standard for future generations. The following is an example from a victim: 
In: Victims and Perpetrators of Terrorism: Exploring identities, roles and narratives. (London: Routledge, 2017: 18-37). Eds: Orla Lynch and Javier Argomaniz.

"I know what my young fella would say to me is 'why weren't youse out shooting all round youse because it seems to me that the ones that are doing the shooting are getting rewarded' what do you say to the young bucks?"41

In addition, usually for the reasons already mentioned, respondents tended to acknowledge that obtaining criminal convictions are unattainable given the challenges:

"The likelihood of people being held to account is very unlikely." 42

Nonetheless, some participants are convinced they have a right to justice:

"We are entitled to it; we don't owe anyone for that."

"It's not necessarily going down the road of prosecution but it's not taking that right away from us. Someone saying you can't have that is an awful kick in the teeth because a lot of victims were murdered upholding the law so they believe they are entitled to that right." 44

In the face of reality constraints, respondents discussed possible alternative avenues to address victims' need for justice. Some spoke of documenting injustices and creating a version of history that is accurate from the viewpoint of victims. For others, however, documenting injustice is seen as an insufficient approach for dealing with the needs of victims: 
In: Victims and Perpetrators of Terrorism: Exploring identities, roles and narratives. (London: Routledge, 2017: 18-37). Eds: Orla Lynch and Javier Argomaniz.

"Some of the groups want to write a report on it, I don't want to write a report, I want to give the woman what she wants. ${ }^{445}$

For representatives of victims, the notion of 'justice' was closely linked to the need to establish the identity of the perpetrators, to hold them accountable for past injustices and establishing criminal prosecutions for them. This would clearly define their role in the conflict in the eyes of those around them. In other words, by making the perpetrators of the violence visible, it would also be possible to clearly identify the victims.

\section{Conclusion}

In this chapter we have explored how victims of terrorism and political violence in the United Kingdom and Spain discussed, in their own voices, some of their social and political needs such as memory, truth and justice. These issues have been studied taking into account the different contexts of violence and the different representations of victimhood in both countries.

From the interviews it can be concluded that the themes of memory, remembrance and memorialisation are closely intertwined with aspects of visibility and recognition. It seems clear that offering victims the possibility of making their own experiences visible and sharing them with other people can be one way of dealing with their own personal trauma and attaining closure. Furthermore, learning about the testimony of victims can 
In: Victims and Perpetrators of Terrorism: Exploring identities, roles and narratives. (London: Routledge, 2017: 18-37). Eds: Orla Lynch and Javier Argomaniz.

also be enriching for the entire society. The visibility and recognition of victims find public expression in commemorative acts, in the creation of monuments, museums, plaques and other markers representing social memories (memorialisation). Conversely, invisibility can represent a traumatic experience for victims, potentially resulting in revictimisation.

In the case of Northern Ireland there was little expectation of recognition and of special treatment since the conceptions of memory, remembrance, and memorialisation reflect the deeply-divided visions present in Northern Ireland's society. In the case of Spain, victims of terrorism linked the need for recognition and remembrance to another issue: the political significance of their victimhood. According to this principle, victims of terrorism contend that they deserve public recognition and remembrance for symbolising with their sacrifice the democratic values that terrorists abhor. Thus, remembering those injured and killed, their innocence and their suffering is an essential part of the identity of victims in Spain and regarded as a tool to de-legitimise terrorism. Memory can also be constructed as a moral duty for society and an instrument for building a shared future without violence for future generations.

In the accounts given by victims in Northern Ireland truth is considered a basic need for obtaining information about what happened in order to piece together an accurate representation of past injustices they and their families suffered. However, although the truth is an important element for their own experiences of victimhood, most participants are sceptical of society's ability to reach a collectively agreed upon and a 'shared truth' about the conflict. Interviewees tend to only report one side of the truth, a 'partial truth' 
In: Victims and Perpetrators of Terrorism: Exploring identities, roles and narratives. (London: Routledge, 2017: 18-37). Eds: Orla Lynch and Javier Argomaniz.

which mirrors the traditional division of the conflict in Northern Ireland. When faced with the question of whether it would be better to achieve a collective truth via the process of truth recovery, many respondents did not believe that this process in Northern Ireland could work at this moment in time.

In the discourse of ETA's victims of terrorism in Spain, exposing the truth about the past is considered a fundamental instrument in the de-legitimisation of the terrorists' rhetoric and a mechanism to prevent the success of their narrative. On the other hand, an absence of truth is regarded as a source of re-victimisation on an individual level that prevents victims from achieving closure and healing.

Justice for victims of terrorism in Spain means recognising the violation of their rights and providing reparation for the harm suffered. Likewise, justice for victims means the arrest, trial and sanction of those responsible for the crimes committed according to the principles of the Rule of Law. In addition, the justice that victims of terrorism in Spain demand can be equated to the absence of impunity.

It must be stressed that different forms and perceptions of justice exist in each particular context. Spanish victims of terrorism adhere to a narrative that seeks retributive justice as a method to ensure the sanction of perpetrators. In Northern Ireland, however, the debate is more wide-ranging with efforts to focus on restorative practices that aim to build bridges between communities, perpetrators and victims but which also attempts to exclude certain individuals (usually the perpetrators) from the category of victim. 
In: Victims and Perpetrators of Terrorism: Exploring identities, roles and narratives. (London: Routledge, 2017: 18-37). Eds: Orla Lynch and Javier Argomaniz.

Therefore it is clear that the social and political needs of victims of terrorism are shaped by the context of the violence experienced. There exist divergent socio-political landscapes and different complex narratives of history with implications for the future separating both case studies. These have an influence on the ways in which victims understand their victimhood and their needs, in particular with regard to visibility, recognition, memory, remembrance, memorialisation, truth and justice.

\section{Bibliography}

Alonso, M. (2009), La razón desposeída de la víctima: La violencia en el País Vasco al hilo de Jean Améry (Victims Deprived of Reasoning: Violence in the Basque Country in Line with Jean Améry). Bilbao: Bakeaz.

Alonso R., Serranò A. (2015), “The needs of victims of terrorism in Spain” in Lynch O., Argomaniz J. (ed.), Victims of Terrorism: a comparative and interdisciplinary study, Routledge, London- New York, pp. 90-106.

Alonso R., (2009) “Justicia, reconciliación y 'procesos de paz' ante fenómenos de violencia política" (Justice, Reconciliation and "Peace Processes" in the Face of Phenomena of Political Violence), Yolanda Gamarra (coord.), Lecciones sobre justicia internacional (Lessons on International Justice), Saragossa, Fundación 
In: Victims and Perpetrators of Terrorism: Exploring identities, roles and narratives. (London: Routledge, 2017: 18-37). Eds: Orla Lynch and Javier Argomaniz.

Fernando el Católico, pp. 53-78.

Alonso R., (2012), "Víctimas y victimarios en la batalla por la legitimidad del terrorismo" (Victims and Perpetrators in the Battle for the Legitimacy of Terrorism), Razón y Fe, n. 265, p. 43-49.

Aulestia K., (1993), Días de viento sur: la violencia en Euskadi (Days of the South Wind: Violence in Euskadi). Barcelona: Editorial Antártida/Empuries.

Arregi J., (2008), “El significado político de las víctimas” (The Political Significance of Victims), paper presented at "III Jornadas Internacionales sobre Terrorismo: Terrorismo y antiterrorism" organised by the Giménez Abad Foundation, held on the $24^{\text {th }}$ and $25^{\text {th }}$ of November 2008 at the Aljafería Palace, seat of Aragon's Regional Parliament, Saragossa.

Arteta A. (2007) “¿Qué víctimas? ¿Qué Justicia?” (Which Victims? What Justice?) in Cuesta C., Alonso R., (eds.), Las víctimas del terrorismo en el discurso político (Victims of Terrorism in the Political Discourse), Fundación Miguel Ángel Blanco, Madrid: Editorial Dilex.

Breen Smyth, M. (2007). Truth Recovery and Justice after the Conflict: Managing Violent Pasts. London: Routledge.

Cory, P. (2003). Cory Collusion Inquiry Report: Chief Superintendent Breen and Super intendent Buchanan. Delivered on 7 October. Available at: http://cain.ulst.ac.uk/issues/ collusion/cory/cory03breenbuchanan.pdf. 
In: Victims and Perpetrators of Terrorism: Exploring identities, roles and narratives. (London: Routledge, 2017: 18-37). Eds: Orla Lynch and Javier Argomaniz.

Cory, P. (2004a). Cory Collusion Inquiry Report: Robert Hamill. London: The
Stationery
Office.
Available
at:

http://cain.ulst.ac.uk/issues/collusion/cory/cory03hamill.pdf.

Cory, P. (2004b). Cory Collusion Inquiry Report: Rosemary Nelson. London: The $\begin{array}{lll}\text { Stationery } & \text { Office. }\end{array}$ http://cain.ulst.ac.uk/issues/collusion/cory/cory03nelson.pdf.

Doak, J. and O’Mahony, D. (2011). 'In Search of Legitimacy: Restorative Youth Conferencing in Northern Ireland', Legal Studies. Available at: www.victimsclearinghouse.

nsw.gov.au/vocrc/victims_clearinghouse_research_database_restorative_doak_s earch. Html

Echeburúa E., (2004), Superar un trauma. El tratamiento de las víctimas de sucesos violentos (Overcoming Trauma. Treating Victims of Violent Acts). Madrid: Pirámide.

Echeburúa E., Guerrica C. (2006), "Especial consideración de algunos ámbitos de victimización" (Special Consideration Regarding some Aspects of Victimisation) in Baca, E., Echeburúa, E. y Tamarit, J. (eds.), Manual de victimología (Victimology Manual). Valencia: Tirant lo Blanch. 
In: Victims and Perpetrators of Terrorism: Exploring identities, roles and narratives. (London: Routledge, 2017: 18-37). Eds: Orla Lynch and Javier Argomaniz.

Etxeberria X. (2009), Identidad como memoria narrada y víctimas del terrorismo (Identity as Narrated Memory and Victims of Terrorism), Bilbao: Bakeaz Escuela de Paz.

González Zorrilla R., Díaz Bada T., "Justicia victimal y valor público del testimonio de las víctimas" (Justice for Victims and the Public Value of the Testimony of Victims), Eguzkilore. Cuaderno del Instituto Vasco de Criminología, n. 26, pp. $173-181$.

Gormally, B. (2006). Community Restorative Justice in Northern Ireland: An Overview. Available at: www.restorativejustice.org/editions/2006/april06/gormallyarticle.

Hamber, B. And Wilson, R. (eds.) (2003) Recognition and reckoning: The way ahead on victims issues (Report 15). Belfast: Democratic Dialogue.

Morland, M., Strachan, V., Burden, A. (2011). The Rosemary Nelson Inquiry Report. London: The Stationery Office.

Lynch, Orla \& Argomaniz, Javier (Coor.) (2013) Good Practices in the Provision of Support Initiatives to Victims of Terrorism. Lessons from the Case of the UK and Spain. Project report for the European Commission (Saint Andrews: University of Saint Andrews) 
In: Victims and Perpetrators of Terrorism: Exploring identities, roles and narratives. (London: Routledge, 2017: 18-37). Eds: Orla Lynch and Javier Argomaniz.

Lynch O, Argomaniz J., Serranò A., et al., "Best Practice Recommendations for Supporting Victims of Terrorism" in Lynch O., Argomaniz J. (ed.), Victims of Terrorism: A Comparative and Interdisciplinary Study, Routledge, London- New York, pp. 149-153, 2015.

Mc Evoy, K. and Mika, H. (2001) Punishment, Politics and Praxis. Restorative Justice and non-

violent alternatives to paramilitaty punishment. Policing and Society, vol. 11(1) 359-82.

McGrattan, C. (2010) Community based restorative justce in Northern Ireland. A neo

traditional paradigm. The British Journal of Politics and International relations, vol. 12

93), pp $425-41$

MacGinty R. (2006), "Northern Ireland: A Peace Process Thwarted by Accidental Spoiling” in Newman E., Richmond O. (ed.), Challenges to Peacebuilding, Managing Spoilers During Conflict Resolution. New York: United Nation Press.

Mata J. M. (1993), El nacionalismo radical vasco: discurso, organización y expresiones (Radical Basque Nationalism: Discourse, Organisation and Expressions, Bilbao: Servicio Editorial, Universidad del País Vasco.

Mate, R. M., (2008), Justicia de las víctimas, terrorismo, memoria, reconciliación (Justice for Victims, Terrorism, Memory, Reconciliation). Barcelona: Anthropos.

Northern Ireland Affairs Committee (NIAC) (2008). Policing and Criminal Justice in Northern Ireland: The Cost of Policing the Past. Available at: www.healingthroughre- 
In: Victims and Perpetrators of Terrorism: Exploring identities, roles and narratives. (London: Routledge, 2017: 18-37). Eds: Orla Lynch and Javier Argomaniz.

membering.org/images/j_library/lib/Policing\%20and\%20Criminal.

Rodríguez Jiménez (1997), La extrema derecha española en el siglo XX (The Extreme Right Wing in Spain in the 20th Century), Madrid: Alianza.

Sabucedo J.M., Blanco A., de la Corte L., (2003). "Beliefs which Legitimise Political Violence Against the Innocent”, Psicothema, Vol. 15 (4), pp. 550-555.

Saville, M., Hoyt, W., Toohey, J. (2010). Report of the Bloody Sunday Inquiry. London: Her Majesty's Stationery Office. Available at: http://report.bloody-sundayinquiry.org/. Accessed June 10th 2017.

Schmid, A. P. (2012) Strengthening the Role of Victims and Incorporating Victims in Efforts to Counter Violent Extremism and Terrorism, ICCT Research Paper (The Hague: ICCT).

Serranò, A. (2015), "Contemporary Anti-Terrorist Policies: Ancient Myths, New Approaches" in Michael Lister and Lee Jarvis (ed.), Critical perspectives on Counter-terrorism, Routledge, (Critical Studies Terrorism Book Series), LondonNew York, 2015, pp. 91-108.

Serranò, A. (2014) "Europa contra el terrorismo, la mirada de la víctima - Europe Against Terrorism, The Glance of the Victim", Catalogue for the photography exhibition "Europa contra el terrorismo: la mirada de la víctima", Fundación Miguel Ángel Blanco, 2014, pp. 1-55 (texts in Spanish and English can be found onhttp://www.fmiguelangelblanco.es/index.php/actividades/accioninternacional/european-project)".

Serranò, A. (2015), “Aprendiendo con las víctimas del terrorismo: lecciones desde la 
In: Victims and Perpetrators of Terrorism: Exploring identities, roles and narratives. (London: Routledge, 2017: 18-37). Eds: Orla Lynch and Javier Argomaniz.

experiencia española" (Learning with Victims of Terrorism: Lessons from the Spanish Experience) in Cuesta C. (Dir. y Coord.), Aprendiendo con las víctimas del terrorismo. Propuesta didáctica para la ciudadanía activa por la Memoria y la Justicia (Learning with Victims of Terrorism. Educational Proposal for Active Citizenship Regarding Memory and Justice, Fundación Miguel Ángel Blanco, 2015, pp. 11-49. ISBN: 978-84-697-2227-5.

Serranò, A. (2012), "La lucha social contra el terrorismo: testimonios de algunas víctimas de ETA" (The social Fight against Terrorism: Testimonies from some of ETA's Victims]) Eguzkilore. Cuaderno del Instituto Vasco de Criminología, n. 26, pp. $253-279$.

Serranò, A. (2009), Le armi razionali contro il terrorismo contemporaneo, le sfide delle democrazie contro la violenzia terroristica (Rational Weapons against Contemporary Terrorism, the Challenge of Democracies against Terrorist Violence), Prologue by Prof. Silvio Gambino (University of Calabria, Italy) and Prof. J. Alberto del Real Alcalá (University of Jaén, Spain), Milan: Giuffrè.

Sutil, L. and Lázaro, E.E. (2007), El dolor incomprendido: el sufrimiento de las víctimas del terrorismo (Unrecognised Pain: The Suffering of Victims of Terrorism). Madrid: Plataforma editorial.

\section{DOCUMENTS:}

Spanish Law 29/2011 on the Comprehensive Recognition and Protection of Victims of Terrorism. 
In: Victims and Perpetrators of Terrorism: Exploring identities, roles and narratives. (London: Routledge, 2017: 18-37). Eds: Orla Lynch and Javier Argomaniz.

Basque Law 4/2008 on the Recognition and Reparation for Victims of Terrorism.

Spanish Constitution (1978).

\section{Endnotes}

${ }^{1}$ The term 'victim' includes both individuals injured and killed and their relatives.

2 McDonald, H. (2014) 'Gerry Adams: I complained formally over police detention'. The Guardian, 2014-57. Available at: http://www.theguardian.com/politics/2014/may/07/gerry-adams-complains-to-policeombudsman-over-detention

${ }^{3}$ The authors would like to thank Cheryl Lawther and Carmel Joyce for their work on this section of the project.

4 Agata Serranò's research was awarded the "Antonio Beristain" prize by the Basque Institute of Criminology (University of the Basque Country, Spain) in 2011.

5 Interviewee - ??

${ }^{6}$ Interviewee - ??

7 Interviewee - ??

${ }^{8}$ Interviewee - ??

9 Interviewee - ??

10 The interviewee cites Art. 1.1 of the Spanish Constitution of 1978: "Spain is hereby established as a social and democratic State, subject to the rule of law, which advocates freedom, justice, equality and political pluralism as the highest values of its legal system."

${ }^{11}$ Interviewee - Victim (Spain).

12 Interviewee - Victim (Spain).

${ }^{13}$ Interviewee - Victim (Spain).

${ }^{14}$ Interviewee - ??

${ }^{15}$ Fundación Centro para la Memoria de las Víctimas del Terrorismo, "Balance del terrorismo en España 2015," Cuadernos del Centro Memorial de las Víctimas del Terrorismo, 1 (Vitoria -Gasteiz: Febrero 2016), pp. 15.

${ }^{16}$ Interviewee - Victim (Spain).

${ }^{17}$ Interviewee - ??

18 Interviewee - Victim's organisation representative (UK).

19 Interviewee - Victim (UK).

${ }^{20}$ Interviewee - ??

${ }^{21}$ An example can be seen examining the ETA's communique of the $20^{\text {th }}$ of October 2011 in which this terrorist group declared the 'end of the armed confrontation between the Basque People and the Spanish State'.

22 Interviewee - Victim's organisation representative (Spain).

${ }^{23}$ Interviewee - Victim (Spain).

${ }^{24}$ Interviewee - Victim's representative (Spain).

25 Interviewee - Victim (Spain). 
In: Victims and Perpetrators of Terrorism: Exploring identities, roles and narratives. (London: Routledge, 2017: 18-37). Eds: Orla Lynch and Javier Argomaniz.

${ }^{26}$ Interviewee - Victim in Northern Ireland (UK).

${ }^{27}$ Interviewee - Victim's organisation representative (UK)

${ }^{28}$ Interviewee - Victim's organisation representative (UK)

${ }^{29}$ Interviewee - Victim in Northern Ireland (UK).

${ }^{30}$ Interviewee - Victim's organisation representative (UK).

31 Interviewee - Victim (Spain).

${ }^{32}$ To explore current legislation in force in Spain regarding material on assistance and reparation for victims of terrorism at a national level, see the Law of Recognition and Comprehensive Protection for Victims of Terrorism (n. 29/2011) and at a local level, see the Basque Parliament's Law on Recognition and Reparation for Victims of Terrorism (n. 4/2008).

${ }^{33}$ Interviewee - Victim (Spain).

${ }^{34}$ With regard to the case of ETA, an official report submitted on the $13^{\text {th }}$ of December 2012 by the Public Prosecutor's Office of the National Court to the Observatory against Impunity, states that since 1978 there are 314 (36.63\%) unpunished ETA murders where the state has failed to bring the perpetrators to justice.

${ }^{35}$ Interviewee - - Victim (Spain).

${ }^{36}$ Interviewee - - Victim (Spain).

37 Interviewee - Victim (Spain).

${ }^{38}$ Interviewee - Victim's organisation representative in Northern Ireland (UK)

${ }^{39}$ Interviewee - Victim's organisation representative in Northern Ireland (UK)

${ }^{40}$ Interviewee - Victim in Northern Ireland (UK).

${ }^{41}$ Interviewee - Victim in Northern Ireland (UK).

${ }^{42}$ Interviewee - Victim's organisation representative in Northern Ireland (UK).

${ }^{43}$ Interviewee - Victim in Northern Ireland (UK).

${ }^{44}$ Interviewee - Victim in Northern Ireland (UK).

${ }^{45}$ Interviewee - Victim's organisation representative in Northern Ireland (UK). 